\title{
Physico-Chemical Analysis of Drinking Water Quality Parameters of Galore Area in Lower Himalayan Region, India
}

\section{Sharma $\mathbf{R K}^{1^{*}}$, Sharma $\mathrm{MR}^{2}$ and Chauhan $\mathrm{SC}^{3}$}

${ }^{1}$ Abhilashi University, Chailchowk, Mandi, Himachal Pradesh, India

${ }^{2}$ School of Sciences and Technology, Career Point University, Hamirpur, Himachal Pradesh, India

${ }^{3}$ Engineering and Management, Abhilashi University, Chailchowk, Mandi, Himachal Pradesh, India

"Corresponding author: Sharma RK, Abhilashi University, Chailchowk, Mandi, Himachal Pradesh, India, Tel: 9418056520; E-mail: ramankumar013@gmail.com Rec date: April 17, 2018; Acc date: April 23, 2018; Pub date: April 27, 2018

Copyright: $\odot 2018$ Sharma RK, et al. This is an open-access article distributed under the terms of the Creative Commons Attribution License, which permits unrestricted use, distribution, and reproduction in any medium, provided the original author and source are credited.

\begin{abstract}
The work presented an analysis of drinking water samples collected from different ground handpumps at 102 sites in Galore area of Dist. Hamirpur, Himachal Pradesh, India. The samples have been analysed for three physicochemical parameters like, $\mathrm{pH}$, conductivity and iron content. The results showed that $\mathrm{pH}$ ranged from 5.9 to 8 , conductivity from 120 to $790 \mu \mathrm{S} / \mathrm{cm}$ and iron content from zero to $3.54 \mathrm{mg} / \mathrm{l}$. The measured parameters of only 33 sites water samples were within the WHO standard drinking quality values whereas in the remaining 69 sites water samples beyond the standard values. In general, the present investigation found that the quality parameters were at the level of pollution at almost more than $65 \%$ sites.
\end{abstract}

Keywords: Physico-chemical quality parameters; Drinking water quality; Water quality standard; Water samples

\section{Introduction}

Water is the elixir of life from the simplest organisms to the most complex human body. It is a significant substance due to the unique physical and chemical properties [1-3]. It has become a survival factor for the sustainable development and the quality of life [4]. Safe drinking water is essential to life and hence satisfactory safe supply of water must be made to the public [5]. The water contaminated with harmful chemicals and pathogens is the cause of diseases amounting to $75 \%$ of the total ones [6]. Based on this fact the determination of water quality is the most important activity for life. Acceptable quality of water shows the safety of drinking water in terms of physical, chemical and bacteriological parameters [7]. The adverse health effects are due to the contaminants that have cumulative toxic properties, such as heavy metals and substances that are carcinogenic [8]. It is found that most common problems in household water supplies may be attributed to hardness, iron, sulfides, sodium chloride, acidity, alkalinity, bacteria and viruses [9].

Therefore, the intake of toxic chemicals is checked from the drinking water which is a very difficult task [10]. Drinking water quality is the major issue in our country and studies related to the drinking water quality of Galore area of Dist. Hamirpur, Himachal Pradesh (HP) have not been conducted. Therefore, the aim of our study of drinking water is to examine the levels of some physicochemical parameters of drinking water of Galore area. Hence, we studied $\mathrm{pH}$, conductivity and iron content levels in the drinking water of the area.

\section{Materials and Methods}

Drinking water samples were collected from Galore area of Dist. Hamirpur, HP, which lies at an altitude of $738 \mathrm{~m}$ above sea level with average temperature of $27^{\circ} \mathrm{C}$.

\section{Selection of the study area}

After scrutinizing many areas, Galore Development Block Area was selected for the collection of groundwater samples to analyze the quality parameters of water due to its problem.

The selection of the area was made on the following reasons:

- Complaints from the consumers for the bad taste and odour of drinking water.

- Visual sign of reddish brown residue in water.

- Staining of clothes and sanitary wares was noticed in the area.

\section{Selection of monitoring stations}

There are 240 groundwater hand pumps in Galore development Block out of which 102 hand pumps were selected at random for the analysis of quality parameters of water. The water samples were collected during the period of September 2015 to May 2016.

\section{Sample collection}

Drinking water samples were collected from 102 sampling sites of Galore Development Block. The samples were collected in plastic polyethylene bottles and then taken to the laboratory in a box having ice in it to avoid the change in water quality parameters. Before the sampling the polyethylene bottles were washed, cleaned and rinsed thoroughly with distilled water. Standard methods [11] were followed for the sample collection and preservation. The goal in the sampling was to collect the samples that are fully descriptive of water quality parameters. Samples collected were as small as possible and sufficient 
Citation: Sharma RK, Sharma MR, Chauhan SC (2018) Physico-Chemical Analysis of Drinking Water Quality Parameters of Galore Area in Lower Himalayan Region, India. J Environ Anal Toxicol 8: 562. doi:10.4172/2161-0525.1000562

Page 2 of 6

for experimentation. The samples were handled in such a manner that their characteristics did not change. Grab samples were collected from the sites as per Standard Methods [11]. Only one sample from each hand pump was collected during the study period.

\section{Determination of physico-chemical parameters of drinking water}

Determination of $\mathrm{pH}$ : The $\mathrm{pH}$ of each sample was measured with the portable $\mathrm{pH}$ meter model $\mathrm{pH} 600$.

Determination of conductivity: Conductivity of each sample is measured by portable conductivity meter model CD600.
Determination of iron content: Iron Content of each sample was determined using Photometer of Hanna Instrument, Inc, USA make. HI 721-25 Iron High Range Reagent was used to measure the iron content in the sample. The resolution of the instrument was $0.01 \mathrm{ppm}$. The photometer was standardized using Standard Reagent.

\section{Results and Discussion}

Values of the measured physico-chemical parameters of drinking water (hand pump samples) are shown in Table 1.

\begin{tabular}{|c|c|c|c|c|c|}
\hline S No & Hand Pump Location & Hand Pump No & $\mathrm{pH}$ & Conductivity & Iron content (ppm) \\
\hline 1 & Lohra & IPH-BSR-GLR-1 & 6.4 & 260 & 0.27 \\
\hline 2 & Near Akash Model School(Galore) & & 6.7 & 270 & 0 \\
\hline 3 & Panyali Jattan & IPH-BSR-GLR-20 & 7 & 200 & 0.21 \\
\hline 4 & Galore Bazzar & IPH-BSR-GLR-2 & 7.2 & 210 & 2 \\
\hline 5 & Budhwin Chowk In H/B & IPH-BSR-GLR-168 & 5.9 & 120 & 0.35 \\
\hline 6 & Baloh Radha Swami & IPH-BSR-GLR-36 & 6.1 & 190 & 0.08 \\
\hline 7 & Kardoh Nr. Guru Dwara & IPH-BSR-GLR-28 & 6.9 & 140 & 0.17 \\
\hline 8 & Nukhel & IPH-BSR-GLR-4 & 6.7 & 350 & 0.42 \\
\hline 9 & Bharari Mata & IPH-BSR-GLR-6 & 6.7 & 190 & 0.21 \\
\hline 10 & Near Patwar Ghar Mair & IPH-BSR-GLR-217 & 6.7 & 330 & 0 \\
\hline 11 & Sukrala Nr.Janj Ghar & IPH-BSR-GLR-39 & 7.5 & 170 & 0.13 \\
\hline 12 & Aghthaan & IPH-BSR-GLR-37 & 7 & 410 & 0.24 \\
\hline 13 & Kai-Di-Bahal-II & IPH-BSR-GLR-21 & 7.2 & 190 & 0.49 \\
\hline 14 & Badaran & IPH-BSR-GLR-165 & 6.9 & 790 & 0 \\
\hline 15 & Galore Hospital & IPH-BSR-GLR-8 & 6.8 & 230 & 0.29 \\
\hline 16 & Panyali Brahmana & IPH-BSR-GLR-24 & 6.8 & 310 & 0 \\
\hline 17 & Panyali & IPH-BSR-GLR-19 & 6.8 & 340 & 0 \\
\hline 18 & Mandyanni Nr. H/O Purshottam Chand & IPH-BSR-GLR-5 & 6.4 & 530 & 0 \\
\hline 19 & Jiana Bazar & IPH-BSR-GLR-26 & 6.7 & 260 & 0.17 \\
\hline 20 & Upper Amroh & IPH-BSR-GLR-10 & 7 & 190 & 1.09 \\
\hline 21 & Jiana Lower (Prem Dass) & IPH-BSR-GLR-25 & 7.1 & 190 & 0.24 \\
\hline 22 & Tagoh Nr Fields & & 6.7 & 350 & 0.15 \\
\hline 23 & Kardoh In Vill & IPH-BSR-GLR-31 & 6.9 & 220 & 0.13 \\
\hline 24 & Baloh Bhuvneshwar Temple & IPH-BSR-GLR-35 & 6.8 & 290 & 0.23 \\
\hline 25 & Panyali Jatttan Nr Kartar House & IPH-BSR-GLR-33 & 8 & 300 & 0.37 \\
\hline 26 & Baloh Nr By Home & & 7.1 & 300 & 0 \\
\hline 27 & Kardoh Nr. Parsottam House & IPH-BSR-GLR-27 & 7.2 & 170 & 1.94 \\
\hline 28 & Kai-Di-Bahal-II & IPH-BSR-GLR-22 & 7 & 230 & 0.08 \\
\hline
\end{tabular}


Citation: Sharma RK, Sharma MR, Chauhan SC (2018) Physico-Chemical Analysis of Drinking Water Quality Parameters of Galore Area in Lower Himalayan Region, India. J Environ Anal Toxicol 8: 562. doi:10.4172/2161-0525.1000562

Page 3 of 6

\begin{tabular}{|c|c|c|c|c|c|}
\hline 29 & Paplah Nr GMS & IPH-BSR-GLR-14 & 6.5 & 250 & 0 \\
\hline 30 & Galore Khas In Vill & IPH-BSR-GLR-60 & 6.3 & 180 & 2.31 \\
\hline 31 & Tagoh Carshed Onkar & IPH-BSR-GLR-16 & 6.7 & 470 & 0.14 \\
\hline 32 & Lower Amroh & IPH-BSR-GLR-11 & 7.8 & 210 & 1.77 \\
\hline 33 & Baloh Nr Curve & & 6.9 & 290 & 1.04 \\
\hline 34 & Sukrala Shiv Mandir & IPH-BSR-GLR-34 & 7.8 & 210 & 0.71 \\
\hline 35 & Raina Middle School & IPH-BSR-GLR-181 & 6.7 & 310 & 0 \\
\hline 36 & Nalangar $\mathrm{Nr}$ GSSS & & 7.1 & 390 & 0.11 \\
\hline 37 & Nehlwin & IPH-BSR-GLR-148 & 6.8 & 470 & 0 \\
\hline 38 & Gahllian $\mathrm{Nr} \mathrm{H} / \mathrm{O}$ Oshiar Singh & IPH-BSR-GLR-179 & 6.6 & 390 & 0.3 \\
\hline 39 & Lower Haretta Nr. Gsss & IPH-BSR-GLR-50 & 6.4 & 330 & 0 \\
\hline 40 & Upper Haretta Nr Sohan Lal House & IPH-BSR-GLR-48 & 6.5 & 240 & 0.19 \\
\hline 41 & Bhallu Nr. H/O Jagar Nath & IPH-BSR-GLR-41 & 6.1 & 530 & 0.12 \\
\hline 42 & Upper Haretta Nr Fateh Chand Shop & IPH-BSR-GLR-45 & 6.8 & 340 & 0.12 \\
\hline 43 & Gahllian GHS & IPH-BSR-GLR-132 & 6.1 & 160 & 0 \\
\hline 44 & Bhallu Nr. H/O Sukh Dev & IPH-BSR-GLR-44 & 6.5 & 150 & 0 \\
\hline 45 & Gahllian Nr H/O Deena Nath & IPH-BSR-GLR-129 & 6.1 & 380 & 0 \\
\hline 46 & Nagehrada Nr. Janj Ghar & IPH-BSR-GLR-137 & 6 & 380 & 0 \\
\hline 47 & Farsi Nr Mouji Ram House & IPH-BSR-GLR-206 & 6.3 & 300 & 0.13 \\
\hline 48 & Raina $\mathrm{Nr} \mathrm{H} / \mathrm{O}$ Harnam Singh & IPH-BSR-GLR-212 & 6.9 & 500 & 0.19 \\
\hline 49 & Gahllian Nr. Harizen Basti & IPH-BSR-GLR-139 & 6.3 & 370 & 0.06 \\
\hline 50 & Dodwin Nr Janj Ghar & IPH-BSR-GLR-54 & 6.4 & 330 & 0.13 \\
\hline 51 & Changer-I & IPH-BSR-GLR-146 & 6.3 & 330 & 0 \\
\hline 52 & Fangsana Nr H/O Roshan Lal & IPH-BSR-GLR-211 & 6.8 & 270 & 0 \\
\hline 53 & Upper Haretta Nr Desh Raj House & IPH-BSR-GLR-47 & 6.1 & 430 & 0.13 \\
\hline 54 & Bhallu Nr. H/O Desh Raj & IPH-BSR-GLR-42 & 6.8 & 350 & 0 \\
\hline 55 & Bhallu Nr. H/O Shakti Chand & IPH-BSR-GLR-40 & 6 & 230 & 1.54 \\
\hline 56 & Bhallu Nr. H/O Sohan Lal & IPH-BSR-GLR-43 & 6.9 & 360 & 0.31 \\
\hline 57 & Nagrereda Nr Junj Ghar & IPH-BSR-GLR-188 & 6 & 350 & 0 \\
\hline 58 & Galot & & 6 & 250 & 0 \\
\hline 59 & Nagrereda Nr Harzen Basti & IPH-BSR-GLR-189 & 6 & 230 & 0 \\
\hline 60 & Galot Khurd -I & IPH-BSR-GLR-143 & 6 & 560 & 0.17 \\
\hline 61 & Lower Haretta Gharan Nr H/O Ravi Dutt & IPH-BSR-GLR-52 & 6.1 & 170 & 0.42 \\
\hline 62 & Galot Kallan & IPH-BSR-GLR-142 & 6.9 & 330 & 0 \\
\hline 63 & Nr Nehelwi & & 6.8 & 320 & 0 \\
\hline 64 & Rahan $\mathrm{Nr} \mathrm{H} / \mathrm{O}$ Mansa Ram & IPH-BSR-GLR-51 & 6 & 250 & 2.05 \\
\hline
\end{tabular}


Citation: Sharma RK, Sharma MR, Chauhan SC (2018) Physico-Chemical Analysis of Drinking Water Quality Parameters of Galore Area in Lower Himalayan Region, India. J Environ Anal Toxicol 8: 562. doi:10.4172/2161-0525.1000562

Page 4 of 6

\begin{tabular}{|c|c|c|c|c|c|}
\hline 65 & Galot-II & IPH-BSR-GLR-151 & 6.9 & 360 & 0 \\
\hline 66 & Galot I & IPH-BSR-GLR-141 & 6.8 & 450 & 0.06 \\
\hline 67 & Shagriani Pump House & IPH-BSR-GLR-52 & 6.3 & 190 & 0.13 \\
\hline 68 & Ropa(Balauni) & IPH-BSR-GLR-227 & 6.8 & 190 & 0 \\
\hline 69 & Balouni & IPH-BSR-GLR-117 & 6.3 & 240 & 0.49 \\
\hline 70 & Dhaned Market & IPH-BSR-GLR-121 & 6.5 & 270 & 3.54 \\
\hline 71 & Upper Ser & IPH-BSR-GLR-118 & 6.1 & 260 & 0.63 \\
\hline 72 & Phal-I & IPH-BSR-GLR-58 & 6.1 & 260 & 0.2 \\
\hline 73 & Phal-II & IPH-BSR-GLR-59 & 6.2 & 200 & 0.21 \\
\hline 74 & Plassi & IPH-BSR-GLR-60 & 6.9 & 350 & 0.3 \\
\hline 75 & Tihri & IPH-BSR-GLR-63 & 7.1 & 120 & 1.9 \\
\hline 76 & Tihri Nr Vijay Sastri House & IPH-BSR-GLR-64 & 7.3 & 120 & 0.16 \\
\hline 77 & Tihri Nr Sharma Niwas & IPH-BSR-GLR-65 & 6.2 & 310 & 0.09 \\
\hline 78 & Phal Nr Surjeet House & IPH-BSR-GLR-66 & 6.8 & 370 & 0.77 \\
\hline 79 & Tihri Nr Hoshiar Singh House & IPH-BSR-GLR- & 6.2 & 300 & 0.07 \\
\hline 80 & Karsai & IPH-BSR-GLR-72 & 7.2 & 200 & 0 \\
\hline 81 & Kultheen Nr Rattan Chand House & IPH-BSR-GLR-73 & 7.1 & 200 & 0.21 \\
\hline 82 & Jharmani Nr Rajinder House & IPH-BSR-GLR-74 & 7 & 210 & 0 \\
\hline 83 & Jharmani Nr Prithvi House & IPH-BSR-GLR-75 & 6.9 & 200 & 0.13 \\
\hline 84 & Jharmani Nr Balvir House & IPH-BSR-GLR-76 & 6.4 & 170 & 0.2 \\
\hline 85 & Dudhana Lohian & IPH-BSR-GLR-78 & 7.1 & 180 & 0.17 \\
\hline 86 & Dudhana & IPH-BSR-GLR-79 & 7.1 & 190 & 1.07 \\
\hline 87 & Than In Vill & IPH-BSR-GLR-82 & 7.1 & 210 & 0.45 \\
\hline 88 & Than Nr Sher Singh House & IPH-BSR-GLR-83 & 7 & 170 & 0 \\
\hline 89 & Gudwin Nr Garden In Vill & IPH-BSR-GLR-85 & 7.6 & 220 & 0.56 \\
\hline 90 & Brahlari Nr Shop Of Rattan Chand & IPH-BSR-GLR-86 & 6.3 & 180 & 0.39 \\
\hline 91 & Nara Janh Ghar & IPH-BSR-GLR-88 & 7.5 & 180 & 0.42 \\
\hline 92 & Dadoh Nr House Of Bhram Dass & IPH-BSR-GLR-95 & 6.8 & 280 & 0.27 \\
\hline 93 & Khorar Nr Guga Temple & IPH-BSR-GLR-96 & 6.7 & 180 & 0.27 \\
\hline 94 & Tippri Near Mango Tree & IPH-BSR-GLR- & 6.1 & 250 & 0.21 \\
\hline 95 & Kotlu Mangat Ram House & IPH-BSR-GLR-108 & 7.2 & 170 & 0.06 \\
\hline 96 & Kotlu Road Side & IPH-BSR-GLR-109 & 7.1 & 280 & 0.31 \\
\hline 97 & IPH Galore Sub Station & IPH-BSR-GLR & 7 & 120 & 0.9 \\
\hline 98 & Near Mango Tree Dadoh & IPH-BSR-GLR-221 & 6.9 & 300 & 0.21 \\
\hline 99 & Bhudwin Chowk In H/B & IPH-BSR-GLR-168 & 7.3 & 290 & 0.36 \\
\hline 100 & Farsi-I & IPH-BSR-GLR-99 & 7 & 290 & 0 \\
\hline
\end{tabular}


Citation: Sharma RK, Sharma MR, Chauhan SC (2018) Physico-Chemical Analysis of Drinking Water Quality Parameters of Galore Area in Lower Himalayan Region, India. J Environ Anal Toxicol 8: 562. doi:10.4172/2161-0525.1000562

Page 5 of 6

\begin{tabular}{|l|l|l|l|l|l|}
\hline 101 & Near Chander Prakash House & IPH-BSR-GLR-222 & 6.9 & 180 & 0.19 \\
\hline 102 & Daswin & IPH-BSR-GLR-223 & 7.1 & 200 & 0 \\
\hline
\end{tabular}

Table 1: Physico-chemical parameters of drinking water.

$\mathrm{pH}$ : Drinking water with $\mathrm{pH}$ between 6.5 to 8.5 is considered satisfactory (WHO permissible value range). If $\mathrm{pH}$ is below 6 , water is corrosive. Water with $\mathrm{pH}$ value above 8.5 has a bitter astringent taste [12]. The $\mathrm{pH}$ of the collected water samples ranged from 5.9 to 8 out of which 68 water samples are having $\mathrm{pH}$ value above 6.5 and less than 8 .

Conductivity: Conductivity is a useful tool to assess the purity of water [13] as it is due to the dissolved electrolytes in water. The permissible limit for conductivity is $300 \mu \mathrm{S} / \mathrm{cm}$. The conductivity of collected water samples ranged from $120-790 \mu \mathrm{S} / \mathrm{cm}$.

Iron content: In this area 102 samples were collected and analyzed. It was observed that 30 samples have no iron present i.e., $29.4 \%$ of samples have no iron content. It was found that 74 samples were having iron content less than $0.3 \mathrm{mg} / \mathrm{l}$ i.e., in $72.5 \%$ of the samples, the iron content in water is within WHO permissible limit. It was observed that 28 samples were having iron content more than $0.3 \mathrm{mg} / \mathrm{l}$ i.e., $27.7 \%$ of the samples have iron content more that permissible limits. It means that $27.7 \%$ of the samples are having iron content more than the maximum permissible limit. It was noted that 11 samples were having iron content more than $1.0 \mathrm{mg} / \mathrm{l}$ i.e., $10.7 \%$ the total samples are analyzed. In 4 samples the iron content was found more than $2 \mathrm{mg} / \mathrm{l}$ i.e., $3.29 \%$ of the total samples. In one sample the iron content was observed more than $3 \mathrm{mg} / \mathrm{l}$ i.e., $0.09 \%$ of the total samples. The range of iron content in samples is from zero $\mathrm{mg} / \mathrm{l}$ to $3.54 \mathrm{mg} / \mathrm{l}$ (Figures 1-6).

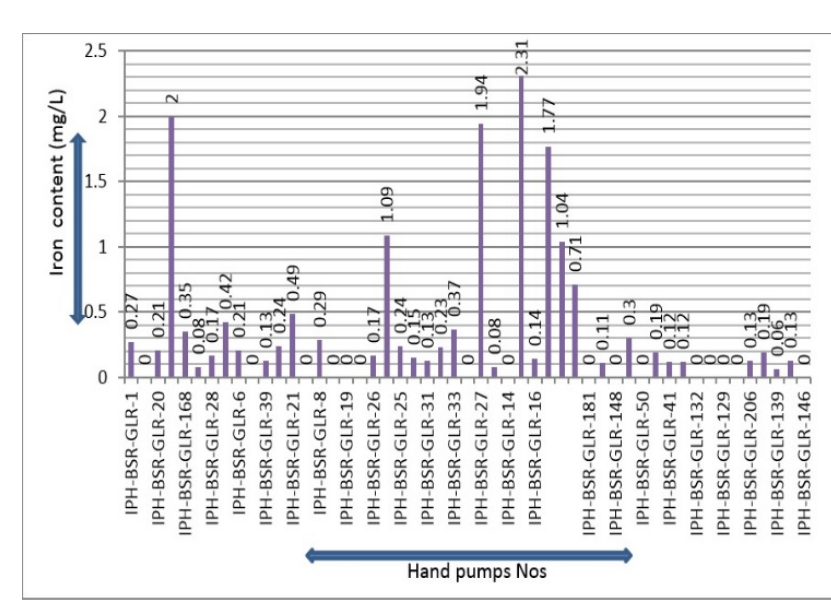

Figure 1: Graph of Iron content for samples 1-25.
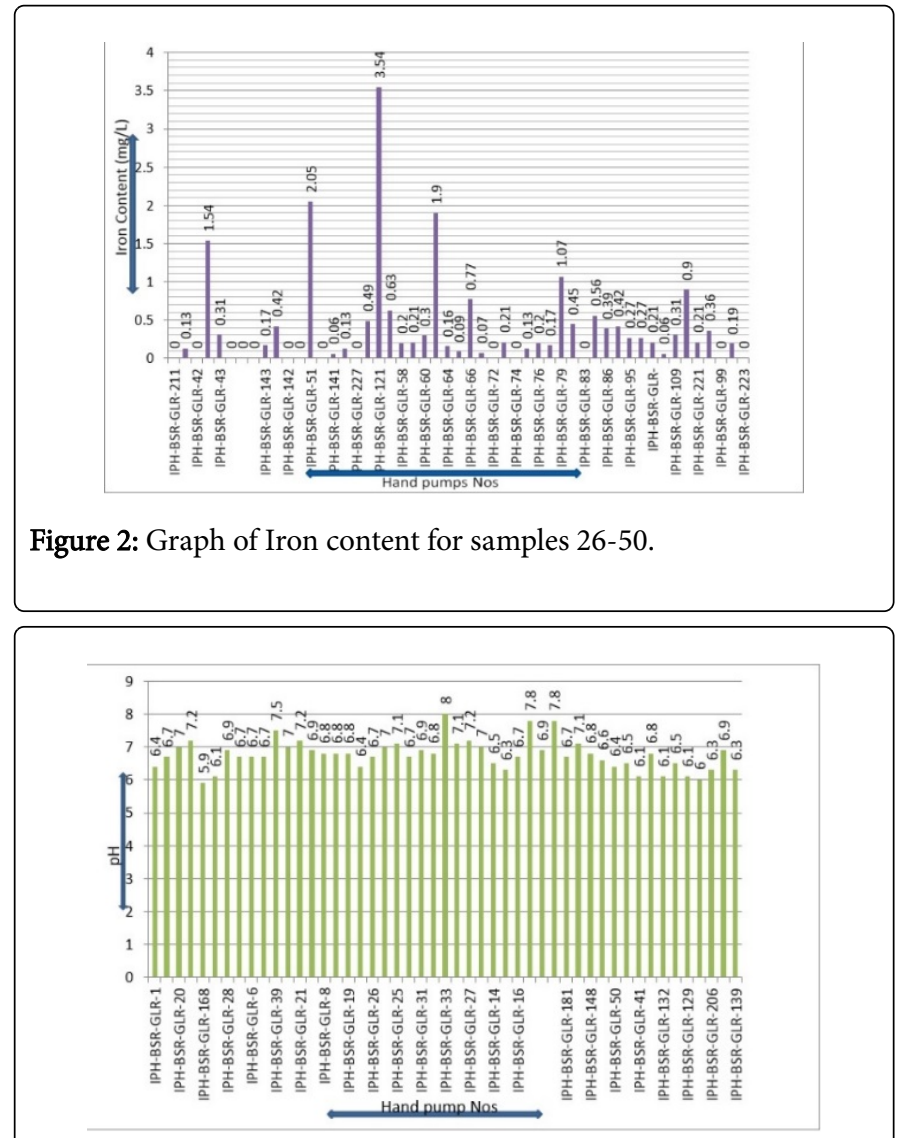

Figure 3: Graph of $\mathrm{pH}$ for samples 1-24.

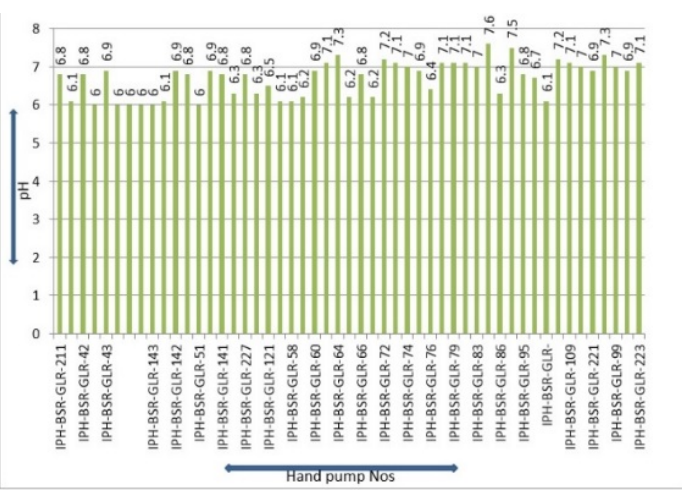

Figure 4: Graph of pH for samples 25-49. 
Citation: Sharma RK, Sharma MR, Chauhan SC (2018) Physico-Chemical Analysis of Drinking Water Quality Parameters of Galore Area in Lower Himalayan Region, India. J Environ Anal Toxicol 8: 562. doi:10.4172/2161-0525.1000562

Page 6 of 6

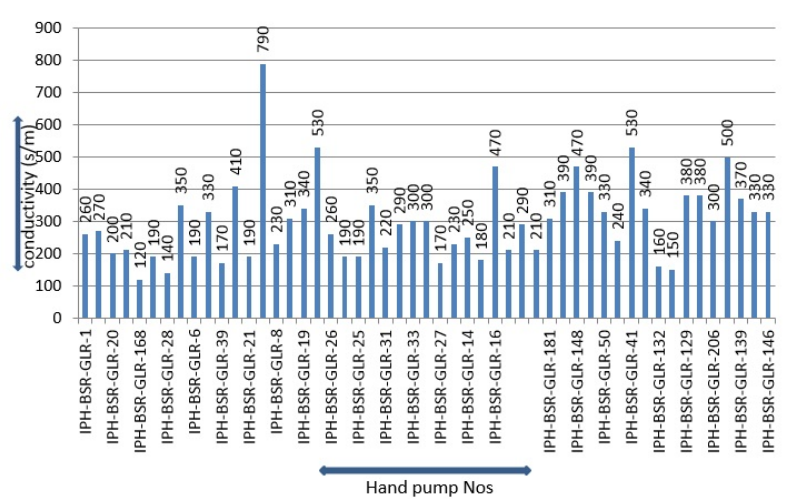

Figure 5: Graph of Electrical Conductivity for samples 1-25.

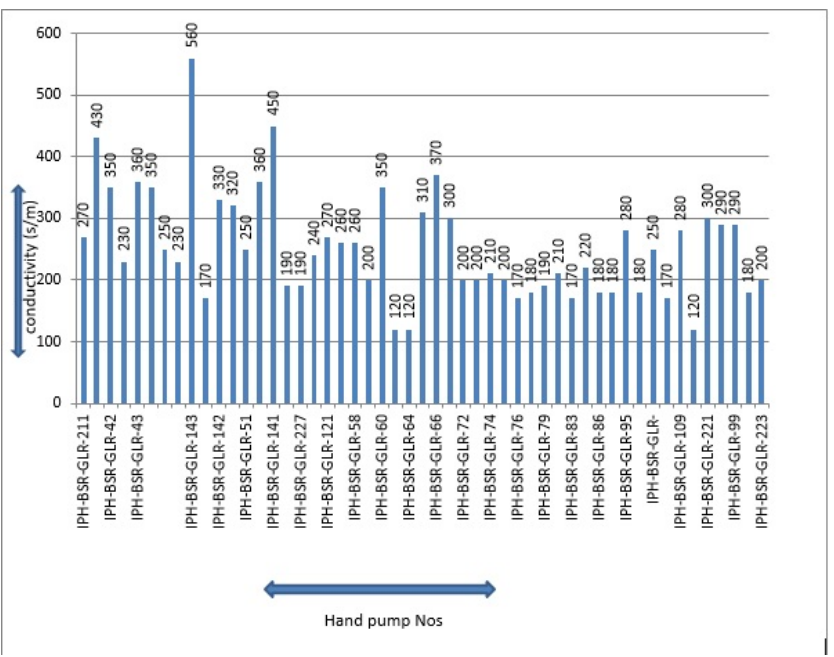

Figure 6: Graph of Electrical Conductivity for samples 26-50.

\section{Conclusion}

A study was carried out to quantify the $\mathrm{pH}$, conductivity and iron content in Galore area of Hamirpur district in Himachal Pradesh. It revealed that keeping in view the permissible values of water quality parameters $(\mathrm{pH}$, conductivity and iron content) only 33 water samples are found fit for drinking purpose and the rest 69 samples are harmful for human consumption.

\section{References}

1. Onifade AK, Ilori RM (2008) Microbiological analysis of sachet water vended in Ondo state, Nigeria. Environ Res J 2: 107-110.

2. Osci Y (2005) New School Chemistry for Senior Secondary Schools. 3rd edn. African First Publisher Ltd, Onitsha, Africa, p: 292.

3. Obi CN, Okocha CO (2007) Microbiological and physicochemical analysis of selected borehole waters. J Enginery Appl Sci 257: 920-929.

4. Eddy NO, Ekop AS (2007) Assessment of the quality of water treated and distributed by the Akwa Ibom state water company. J Chem 4: 180-186.

5. Ackah M, Anim AK, Gyamfi ET, Acquah J, Nyarko ES, et al. (2012) Assessment of the quality of sachet water consumed in urban townships of Ghana using physico-chemical indicators: A preliminary study. Adv Appl Sci Res 3: 2120-2127.

6. WHO (2000) Disinfectants and disinfectant by products. Environmental Health Criteria 216, Geneva: World Health Organization, Switzerland.

7. WHO (2004) Guidelines for Drinking-water Quality. Geneva: World Health Organization, Switzerland.

8. Department of the Environment, Welsh Office (DEWO) (1989) Guidance and safeguarding the quality of public water suppliers. Her Majesty's Stationery Office London, England.

9. Saleh MA, Emmanuel E, Joseph J, Wilson BL (2001) Chemical evaluation of commercial bottled drinking water from Egypt. J Food Comp Anal 14: 127-152.

10. Danish W (2003) Technical support document on drinking water standard objectives and guide lines.

11. APHA (2005) Standard methods for the examination of water and waste water. Washington, DC: American Public Health Association, USA.

12. Reda AH (2016) Physico-Chemical Analysis of Drinking Water Quality of Arbaminch Town. J Environ Anal Toxicol 6: 1-5.

13. Singh B, Singh Y, Sekhon GS (1995) Fertilizer-N use efficiency and nitrate pollution of groundwater in developing countries. J Contam Hydrol 20: 167-184. 